\title{
Differentiation of hematopoietic stem cell and myeloid populations by ATP is modulated by cytokines
}

\author{
CMV Barbosa', CMMP Leon ${ }^{1}$, A Nogueira-Pedro', F Wasinsk, RC Araújo', A Miranda', AT Ferreira ${ }^{1}$ and EJ Paredes-Gamero*,1,2
}

Extracellular nucleotides are emerging as important regulators of inflammation, cell proliferation and differentiation in a variety of tissues, including the hematopoietic system. In this study, the role of ATP was investigated during murine hematopoiesis. ATP was able to reduce the percentage of hematopoietic stem cells (HSCs), common myeloid progenitors and granulocytemacrophage progenitors (GMPs), whereas differentiation into megakaryocyte-erythroid progenitors was not affected. In addition, in vivo administration of ATP to mice reduced the number of GMPs, but increased the number of Gr- $1^{+}$Mac- $1^{+}$myeloid cells. ATP also induced an increased proliferation rate and reduced Notch expression in HSCs and impaired HSC-mediated bone marrow reconstitution in sublethally irradiated mice. Moreover, the effects elicited by ATP were inhibited by suramin, a P2 receptor antagonist, and BAPTA, an intracellular $\mathrm{Ca}^{2+}$ chelator. We further investigated whether the presence of cytokines might modulate the observed ATP-induced differentiation. Treatment of cells with cytokines (stem cell factor, interleukin-3 and granulocyte-monocyte colony stimulator factor) before ATP stimulation led to reduced ATP-dependent differentiation in longterm bone marrow cultures, thereby restoring the ability of HSCs to reconstitute hematopoiesis. Thus, our data suggest that ATP induces the differentiation of murine HSCs into the myeloid lineage and that this effect can be modulated by cytokines.

Cell Death and Disease (2011) 2, e165; doi:10.1038/cddis.2011.49; published online 2 June 2011

Subject Category: Immunity

Under steady-state conditions, hematopoietic bone marrow cells develop in intimate association with a highly organized, three-dimensional microenvironment. This structural scaffold is composed of many cell types, including osteoblasts and stromal cells, as well as their associated biosynthetic products: components of the extracellular matrix, adhesion molecules and hematopoietic growth factors. ${ }^{1}$ The specific bone marrow microenvironment in which hematopoietic stem cells (HSCs) reside is referred to as the stem cell niche. HSCs are a subset of bone marrow cells that are capable of self-renewal and of forming all types of blood cells. ${ }^{2}$ The hematopoietic niche has an essential role in regulating the self-renewal and differentiation of stem cells. In the bone marrow, two stem niches have been characterized: the osteoblastic niche, where osteoblasts primarily control the quiescence and asymmetric proliferation of HSCs, ${ }^{3}$ and the vascular niche, which is mainly associated with myeloid differentiation. ${ }^{4}$

The cells present in hematopoietic niches regulate hematopoiesis through the release of different cytokines, which then activate distinct cytokine receptors with intrinsic kinase activity or Janus kinase-dependent receptors. However, new families of G-protein-coupled receptors and ion channels have been recently associated with the regulation of hematopoiesis, ${ }^{5}$ such as the P2 receptor family, which is activated by extracellular nucleotides. ${ }^{6,7}$ These extracellular nucleotides are released by endothelial and osteoblast cells, ${ }^{8-10}$ and may be associated with myeloid differentiation. ${ }^{6}$

The functions of ATP are mediated by receptors of the P2 receptor family, which are further divided into the $P 2 X$ (ionotropic receptor) and P2Y (metabotropic receptor) subfamilies. ${ }^{11} \mathrm{P} 2$ receptor activation triggers many physiological responses in various cell types that are mediated by a $\mathrm{Ca}^{2+}$ influx through the $\mathrm{P} 2 \mathrm{X}$ receptor or via intracellular $\mathrm{Ca}^{2+}\left(\mathrm{Ca}_{\mathrm{i}}^{2+}\right)$ release by $\mathrm{P} 2 \mathrm{Y}$ receptors that activate phospholipase C (PLC). PLC hydrolyzes phosphatidylinositol-4,5-bisphosphate and a subsequent increase in inositol 1,4,5-trisphosphate $\left(\operatorname{lnsP}_{3}\right)$ and diacylglycerol (DAG) occurs. ${ }^{12}$ In addition, changes in the level of adenylate cyclase activity have been shown to influence the concentration of cyclic adenosine monophosphate. ${ }^{13,14}$ The activation of P2 receptors controls other intracellular pathways by changing the concentration levels of $\mathrm{Ca}_{i}^{2+}$ and cyclic adenosine monophosphate, modulating the mitogen-activated protein kinases and phosphoinositide 3-kinase, both related with proliferation and differentiation. ${ }^{15,16}$

In hematopoietic cells, treatment with ATP leads to cellular activation, with an increase in proinflammatory activities, cell

\footnotetext{
${ }^{1}$ Departamento de Biofísica, Universidade Federal de São Paulo, Rua Botucatu 862, 2 `Andar, 04023-062 São Paulo, Brazil and ${ }^{2}$ Departamento de Bioquímica, Universidade Federal de São Paulo, Rua Três de Maio 100, 04044-020 São Paulo, Brazil

${ }^{*}$ Corresponding author: EJ Paredes-Gamero, Departamento de Biofísica, Universidade Federal de São Paulo, Rua Botucatu 862, $2^{\circ}$ Andar, 04023-062, São Paulo, Brazil. Tel: + 55115572 4583; Fax: + 55115571 5780; E-mail: edgar.gamero@unifesp.br

Keywords: ATP; P2 receptors; hematopoietic stem cell; differentiation; myeloid; cytokines

Abbreviations: BFU-E, burst-forming units-erythroid; CaSR, calcium-sensing receptors; CFU-GM, colony-forming units of granulocytes and macrocytes; CMP, common myeloid progenitors; GMPs, granulocyte-macrophage progenitors; CxCR4, CxC chemokine receptor 4; DAG, diacylglycerol; GM-CSF, granulocyte-monocyte colony stimulator factor; $\mathrm{HP}$, hematopoietic progenitor; $\mathrm{HSCs}$, hematopoietic stem cells; InsP $\mathrm{P}_{3}$, inositol 1,4,5-trisphosphate; IL-3, interleukin-3; $\mathrm{Ca}_{i}^{2+}$, intracellular $\mathrm{Ca}^{2+}$; Lin, lineage marker cocktail; LTBMCs, long-term bone marrow cultures; MEPs, megakaryocytic-erythroid progenitors; MP, myeloid progenitor; PLC, phospholipase C; SCF, stem cell factor

Received 24.1.11; revised 05.4.11; accepted 28.4.11; Edited by A Stephanou
} 
death, ${ }^{17,18}$ platelet aggregation, ${ }^{14}$ and cellular proliferation and differentiation. ${ }^{6,7}$ Studies in promyelocytic leukemia HL-60 cells have shown that the expression levels of P2 receptors change significantly during myeloid differentiation. ${ }^{19,20}$ Nucleotides such as ATP and UTP enhance the response of HSCs to several cytokines. ${ }^{7}$ For example, UTP was able to significantly improve chemokine receptor 4-mediated (CxC4R) HSC migration. ${ }^{21}$ In addition, we have shown that large increases in ATP-induced $\mathrm{Ca}_{i}^{2+}$ promote transient proliferation and induce the differentiation of primitive hematopoietic cells in long-term bone marrow cultures (LTBMCs). ${ }^{6}$ Recently, the functional presence of $\mathrm{P} 2 \mathrm{X}$ receptors was described in an HSC subset, which is probably related to proliferation. ${ }^{22}$

To understand the physiological role of $\mathrm{P} 2$ receptors in the hematopoietic system, the capacity of extracellular ATP to promote differentiation was investigated in the bone marrow. Furthermore, the ability of cytokines to inhibit ATP-dependent differentiation was explored. Our data show that extracellular ATP induces a reduction in the number of HSCs and myeloid progenitors (MPs), which leads to an increase of mature myeloid cells in the bone marrow, and that this effect can be modulated by the presence of cytokines.

\section{Results}

ATP induces changes in the percentage of primitive and mature bone marrow populations. Because ATP induces the differentiation of primitive cells in LTBMCs, we determined whether ATP stimulation could alter the percentages of the HSC and MP populations, including the common myeloid progenitors (CMPs), granulocytemacrophage progenitors (GMPs) and megakaryocyticerythroid progenitors (MEPs). An HSC phenotype was defined in this study as $\mathrm{Lin}^{-} \mathrm{C}-\mathrm{Kit}^{+} \mathrm{Sca}-1^{+} \mathrm{Thy} 1.1^{+} \mathrm{Flk} 2^{-}$, a subset capable of extensive self-renewal and differentiation into all types of blood cells. ${ }^{23}$ Other myeloid progenitors were recognized as described in previous reports. ${ }^{2,23}$ The identification of the populations used in this study is provided in the Supplementary information (Supplementary Figure 1). For this purpose, bone marrow cells were stimulated with ATP at different times and concentrations. Following stimulation, the samples were labeled to permit the identification of primitive hematopoietic populations by flow cytometry. A high concentration of ATP $(1 \mathrm{mM})$ was required to promote different effects in the hematopoietic cells. ${ }^{7,24}$ However, this concentration did not induce hematopoietic cell death ${ }^{6,17}$ (Supplementary Figure 2). Concentrations lower than $1 \mathrm{mM}$ did not induce significant changes in the percentage of HSCs (Supplementary Figure 3).

Our results showed a significant decrease in the percentage of the HSC (to $44 \%$ of untreated levels), CMP (to $28 \%$ of untreated levels) and GMP (to $27 \%$ of untreated levels) populations after stimulation with ATP for $4 \mathrm{~h}$ in vitro (Figure 1a), whereas the MEP population was not affected. Similar results were obtained by stimulation performed in short culture for $12 \mathrm{~h}$ (Supplementary Figure 4A).

To verify the ATP-induced differentiation, a dose of $0.47 \mathrm{~g} / \mathrm{kg}$ of ATP was administered in vivo for 4 days. This dose injected intraperitoneally has been used previously in other studies to stimulate P2 receptors and did not induce adverse effects in the treated animals. ${ }^{25,26}$ After treatment with ATP, bone marrow cells were collected for immunophenotyping. An evaluation of the hematopoietic cell populations showed a significant reduction in GMPs (40\%). The HSC population was reduced in $35 \%$ (of untreated levels), although this did not constitute a significant decrease, whereas the CMP and MEP populations were not affected (Figure 1b). Furthermore, an evaluation of the mature myeloid population $\left(\mathrm{Gr}-1^{+} \mathrm{Mac}-1^{+}\right)$ from experiments performed in vivo indicated a significant increase (43\%) after 4 days of treatment (Figure 1c).

In additionally, suramin, a P2 antagonist were used to verify the participation of $\mathrm{P} 2$ receptors in the observed effects. Suramin was able to inhibit the decrease of the hematopoietic cell populations induced by ATP, both in vivo and in vitro (Figure 1a and b). Moreover, in the absence of ATP, suramin did not affect the percentage of hematopoietic populations (Supplementary Figures 4B and C). Furthermore, adenosine, which is produced by ATP degradation activating P1 receptors, and xanthine, an adenosine receptor antagonist, were used to evaluate P1 receptors' involvement. From our results, we observed that adenosine did not reduce the percentage of hematopoietic populations (Supplementary Figures $5 \mathrm{~A}$ and $\mathrm{B}$ ) and that xanthine did not abolish the effect of ATP in vivo and in vitro (Supplementary Figures $5 C$ and D).

Furthermore, the number of colony-forming units of granulocytes and macrocytes (CFU-GM) and burst-forming units-erythroid (BFU-E) was quantified using methylcellulose assays. ATP induced a $42 \%$ reduction in the number of CFU-GM, but did not alter the number of BFU-E (Figure 1d). Concentrations lower than $1 \mathrm{mM}$ did not induce significant changes in the percentage of CFU-GM colonies (Supplementary Figure 6). These data strongly suggest that ATP is involved in myeloid differentiation, reducing primitive MPs and increasing their mature forms.

Moreover, as the presence of macrophages in whole bone marrow could participate indirectly in the effects of differentiation induced by ATP, the same test was conducted with isolated $\mathrm{c}-\mathrm{Kit}^{+}$cells cultured on the stroma cell line MS5 for $24 \mathrm{~h}$. Similar effects of differentiation in response to ATP were observed in the absence of macrophages (Figure 1e).

ATP reduces HSC potency. Subsequently, other tests were performed to verify the ability of ATP to promote myeloid differentiation, and important features of HSCs were evaluated, such as exhibiting a quiescent state, Notch receptor expression and the ability of HSCs to repopulate the bone marrow. We measure the proliferative state using an antibody against $\mathrm{Ki}-67$ protein, which is specifically expressed during all active phases of the cell cycle, but is absent from resting cells. Stimulation of bone marrow cells with ATP induced an increase of the HSC-Ki- $67^{+}$population from $20 \pm 1$ to $46 \pm 3 \%$, showing that ATP induces HSC proliferation (Figure 2a). Notch receptors have been associated with the self-renewal, quiescence, maintenance and differentiation of HSC, and its expression is used as an indicator of the undifferentiated state of HSC. ${ }^{27,28}$ Stimulation of bone marrow cells with $1 \mathrm{mM}$ ATP for 2 or $4 \mathrm{~h}$ led to a marked reduction in the Notch receptor expression of the 

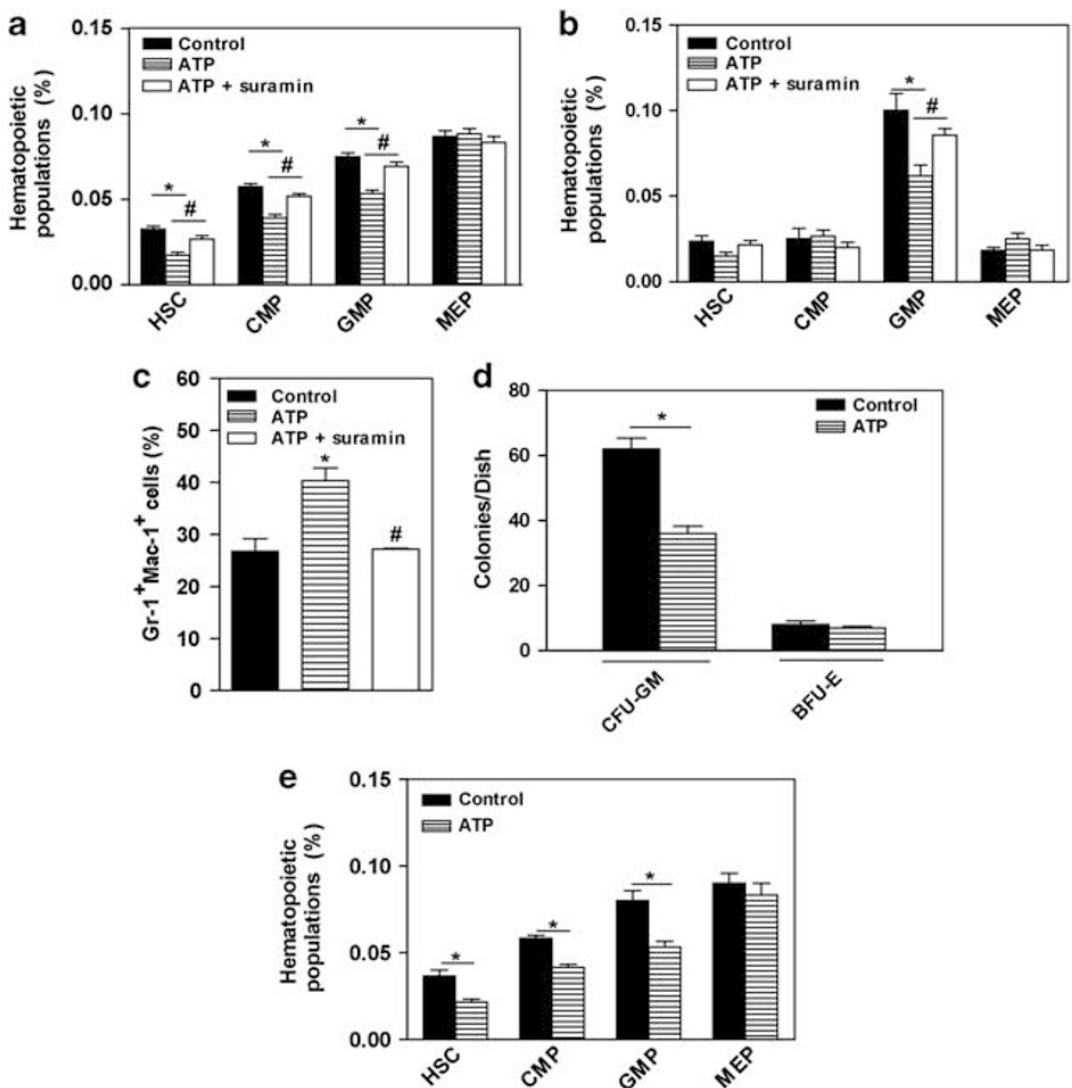

Figure 1 ATP decreases the percentages of murine primitive hematopoietic cell populations. (a) Bone marrow suspensions were stimulated with $1 \mathrm{mM}$ ATP for $4 \mathrm{~h}$, and the hematopoietic populations present were quantified, $n=6$. Hematopoietic stem cell (HSC), common myeloid progenitor (CMP) and granulocyte-macrophage progenitor (GMP) populations were reduced by stimulation with ATP, whereas megakaryocytic-erythroid progenitors (MEPs) were not affected. (b and $\mathbf{c}$ ) Mice were treated in vivo with ATP $(47 \mathrm{mg} / \mathrm{kg})$ for 4 days, $n=6$. (b) ATP significantly reduces the GMP population (c) and increases the number of mature myeloid cells $\left(\mathrm{Gr}-1^{+} \mathrm{Mac}-1^{+}\right)$. (a-c) The effects induced by ATP were abolished in the presence of suramin, a P2 receptor antagonist. (a) In vitro experiment: suramin $100 \mu \mathrm{M}$. (b and c) In vivo experiment: suramin $10 \mathrm{mg} / \mathrm{ml}$. (d) $\mathrm{c}-\mathrm{Kit}^{+} \mathrm{Lin}^{-}$cells were plated in methylcellulose in the presence or absence of $1 \mathrm{mM} \mathrm{ATP,} n=4$. ATP was able to partially reduce the number of CFU-GM colonies. (e) In addition, the same experiment shown in (a) was performed with an isolated $\mathrm{c}-\mathrm{Kit}^{+} \mathrm{Lin}^{-}$population on the stroma cell line MS5. Similar results were obtained under these conditions, $n=4$. Data are expressed as the mean \pm S.E.M. ${ }^{*, \#} P<0.05$. ${ }^{*}$ Statistical analysis was performed against a control. " Statistical analysis was performed against samples stimulated with ATP. (a, $\mathbf{b}$ and $\mathbf{c})$ ANOVA test. (d and $\mathbf{e}) t$-test

HSC and MP populations (Figure $2 \mathrm{~b}$ ). In addition, an evaluation of the competence of HSCs to repopulate the bone marrow microenvironment after stimulation with $1 \mathrm{mM}$ ATP was performed using transgenic mice expressing the green fluorescent protein (GFP). Freshly isolated bone marrow cells from GFP animals were stimulated with ATP for $4 \mathrm{~h}$ and immediately injected by retro-orbital injection into sublethally irradiated (700 Gy) wild-type animals. After 8 weeks, the animals were killed, and the frequency of $\mathrm{GFP}^{+}$cells within the different hematopoietic populations was determined. The hematopoietic populations from the ATP-stimulated group showed a clear reduction in the frequency of $\mathrm{GFP}^{+}$cells compared with controls, indicating a decrease in the ability of ATP-treated HSCs to reconstitute the hematopoietic system (Figure 2c) Furthermore, the expression of CxCR4 and calcium-sensing receptors (CaSR), which are homing receptors of HSCs, were evaluated. Stimulation of bone marrow cells in vitro did not alter CxCR4 or CaSR expression (Supplementary Figures 7A and B).

Osteoblastic and endothelial niches regulate the quiescent state of HSCs. Therefore, if ATP induces HSC differentiation, then it will likely result in a high level of expression of ectonucleotidases in hematopoietic progenitors (HPs) and osteoblast cells. The expression of CD39 and CD73, which hydrolyze ATP into ADP and AMP into adenosine, respectively, was analyzed in freshly isolated bone marrow cells. HSC, HP and stromal cells express CD39 and CD73 (Supplementary Figures 7C-F). Moreover, activity of ectonucleotidases was compared among three populations: immature hematopoietic population (c-Kit ${ }^{+}$cells), stromal cells $\left(\right.$ CD $45^{-}$Ter- $\left.119^{-}\right)$and mature cells of bone marrow (whole bone marrow cells). We observed that immature hematopoietic cells exhibit a higher ectonucleotidase activity than mature or stromal cells (Supplementary Figure 8).

ATP promotes increased $\left[\mathrm{Ca}^{2+}\right]_{i}$ in hematopoietic cells. The observed ATP-induced differentiation in LTBMCs is related to a large increase in $\mathrm{Ca}_{\mathrm{i}}^{2+} .6$ To verify that the differentiation of primitive bone marrow hematopoietic cells is dependent on $\mathrm{Ca}_{\mathrm{i}}^{2+}$ signaling, initial measurements of $\mathrm{Ca}_{\mathrm{i}}^{2+}$ were carried out in freshly isolated 
a

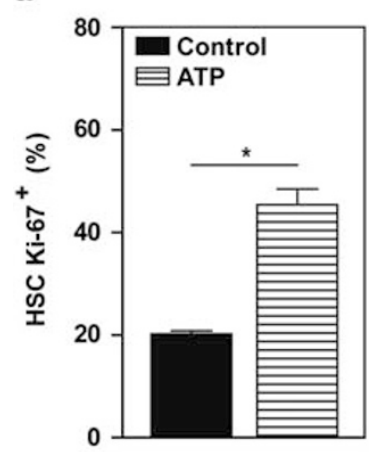

b
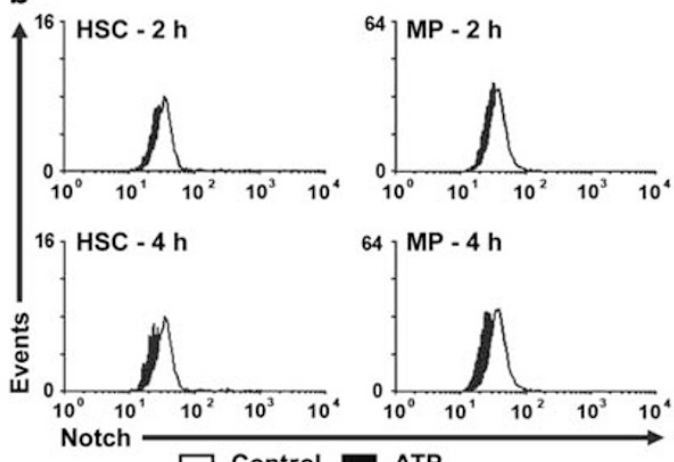

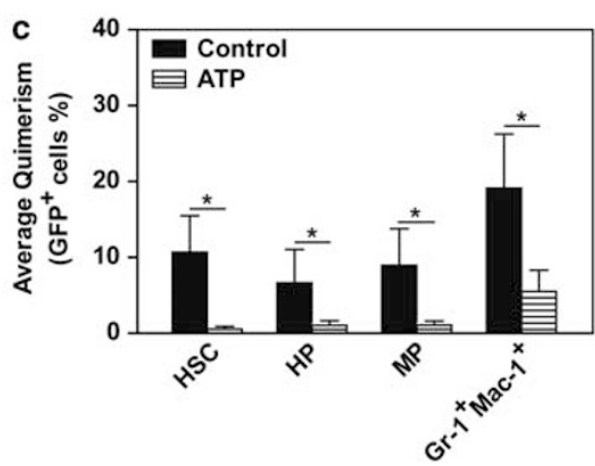

Figure 2 ATP decreases the undifferentiated characteristics of hematopoietic stem cells (HSCs). (a) Stimulation of bone marrow cells with ATP for $4 \mathrm{~h}$ induces an increase of Ki-67 expression in HSCs. (b) A reduction in Notch expression was observed after ATP treatment. The graphs are representative of three independent experiments. Open histogram: unstimulated sample. Filled histogram: stimulated sample. (c) Bone marrow cells from green fluorescent protein (GFP) mice were stimulated with $1 \mathrm{mM}$ ATP for $4 \mathrm{~h}$ and transferred to non-lethally irradiated mice. After 8 weeks, the animals that received GFP ${ }^{+}$cells were killed, and the percentage of GFP ${ }^{+}$cells was quantified in each population: HSCs, hematopoietic progenitors (HPs), myeloid progenitors (MPs) and the mature myeloid population $\left(\mathrm{Gr}-1^{+} \mathrm{Mac}-1^{+}\right)$. The stimulation of hematopoietic cells with ATP led to a decrease in the capacity of HSCs to reconstitute bone marrow. (a and $\mathbf{c}$ ) Data are expressed as the mean \pm S.E.M. ${ }^{*} P<0.05$, (a and $\left.\mathbf{c}\right) t$-test. $n=5-7$

HSC and C-Kit ${ }^{+}$Lin $^{-}$populations (a population that contains HPs). After separation, the cells were loaded with the $\mathrm{Ca}^{2+}$ indicator Fluo-4-AM, and the emission of fluorescence was visualized by confocal microscopy. The $\mathrm{Ca}_{i}^{2+}$ concentration was represented as a temporal insensitive graph or as representative pseudocolored images. As shown in Figure 3a, ATP promoted a transient increase in the $\mathrm{Ca}_{i}^{2+}$ concentration in both primitive populations. Then, the $\mathrm{Ca}_{i}^{2+}$ chelator BAPTA-AM was used to verify the participation of $\mathrm{Ca}_{i}^{2+}$ in ATP-induced differentiation. BAPTA-AM was incubated with fresh bone marrow cells for $1 \mathrm{~h}$ before stimulus with ATP. The $\mathrm{Ca}_{\mathrm{i}}^{2+}$ chelator was able to abolish the in vitro ATP-induced differentiation.

Cytokines modulate the observed ATP-induced differentiation. Cytokines and ATP may be released by cells in hematopoietic stem cell niches. Thus, these molecules may regulate HSC activity together. We investigated whether the presence of cytokines could modulate the differentiation induced by ATP. For this purpose, known differentiation effects of ATP were induced to evaluate whether the previous stimulation of cytokines altered the response to ATP.

First, we evaluated whether the addition of cytokines could alter the ATP-dependent increase in the $\mathrm{Ca}_{i}^{2+}$ concentration because the effects of ATP-dependent differentiation occur mainly via increased $\mathrm{Ca}_{\mathrm{i}}^{2+}$ (Figure 3). We observed that a previous $5 \mathrm{~min}$ stimulation with cytokines (granulocytemonocyte colony stimulator factor (GM-CSF), interleukin-3 (IL-3) and stem cell factor (SCF) at $10 \mathrm{ng} / \mathrm{ml}$ ) partially reduced the ATP-dependent increase in the $\mathrm{Ca}_{i}^{2+}$ concentration in LTBMCs. The $\mathrm{Ca}_{i}^{2+}$ concentration was represented as a graph of fluorescence intensity versus time or as pseudocolor images. Representative images are shown in Figure $4 \mathrm{a}$ and the temporal $\mathrm{Ca}_{i}^{2+}$ concentration values are shown in Figure 4b. The increase in $\mathrm{Ca}_{i}^{2+}$ was normalized using the $\mathrm{Ca}^{2+}$ ionophore A23187 (Response 100\%). A23187 forms membrane channels that allow the passage of $\mathrm{Ca}^{2+}$ to the cytoplasm.

Second, we determined whether cytokines could prevent ATP-dependent differentiation in LTBMCs, as reported previously. ${ }^{6}$ LTBMCs were incubated with GM-CSF, SCF and IL3 for $5 \mathrm{~min}$ and subsequently stimulated with ATP $(1 \mathrm{mM})$. The cells were collected after 3 days of stimulation, and the percentages of the different populations were analyzed by flow cytometry. Our results showed that the presence of cytokines $(10 \mathrm{ng} / \mathrm{ml})$ abolished the increase in the mature myeloid population $\left(\mathrm{Gr}-1^{+} \mathrm{Mac}-1^{+}\right.$) elicited by $1 \mathrm{mM}$ ATP (Figure $5 \mathrm{a}$ ). The presence of cytokines also inhibited the ATPdependent decrease in primitive cells $\left(\mathrm{Gr}-1^{-} \mathrm{Mac}-1^{-} \mathrm{C}-\mathrm{Kit}^{+}\right)$in LTBMCs (Figure $5 \mathrm{~b}$ ). In addition, Giemsa/May-Grünwald staining was performed to corroborate the flow cytometry 
a
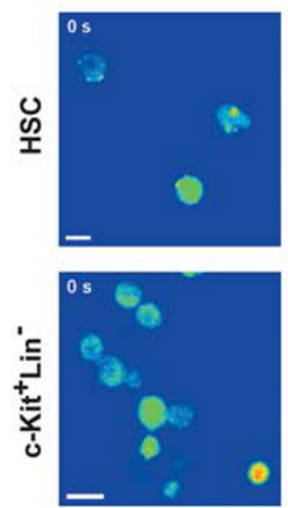
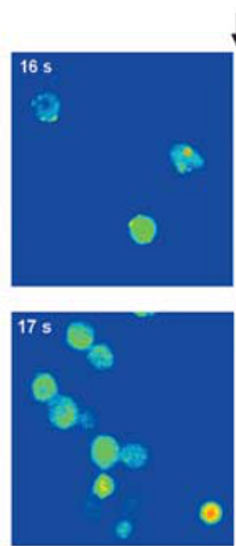

0
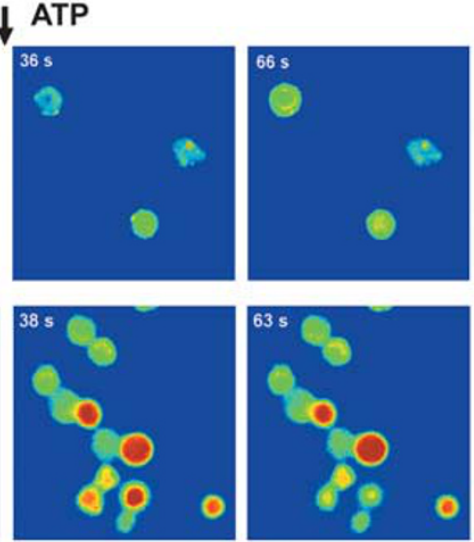

255
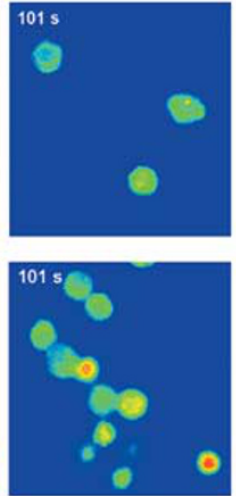

O
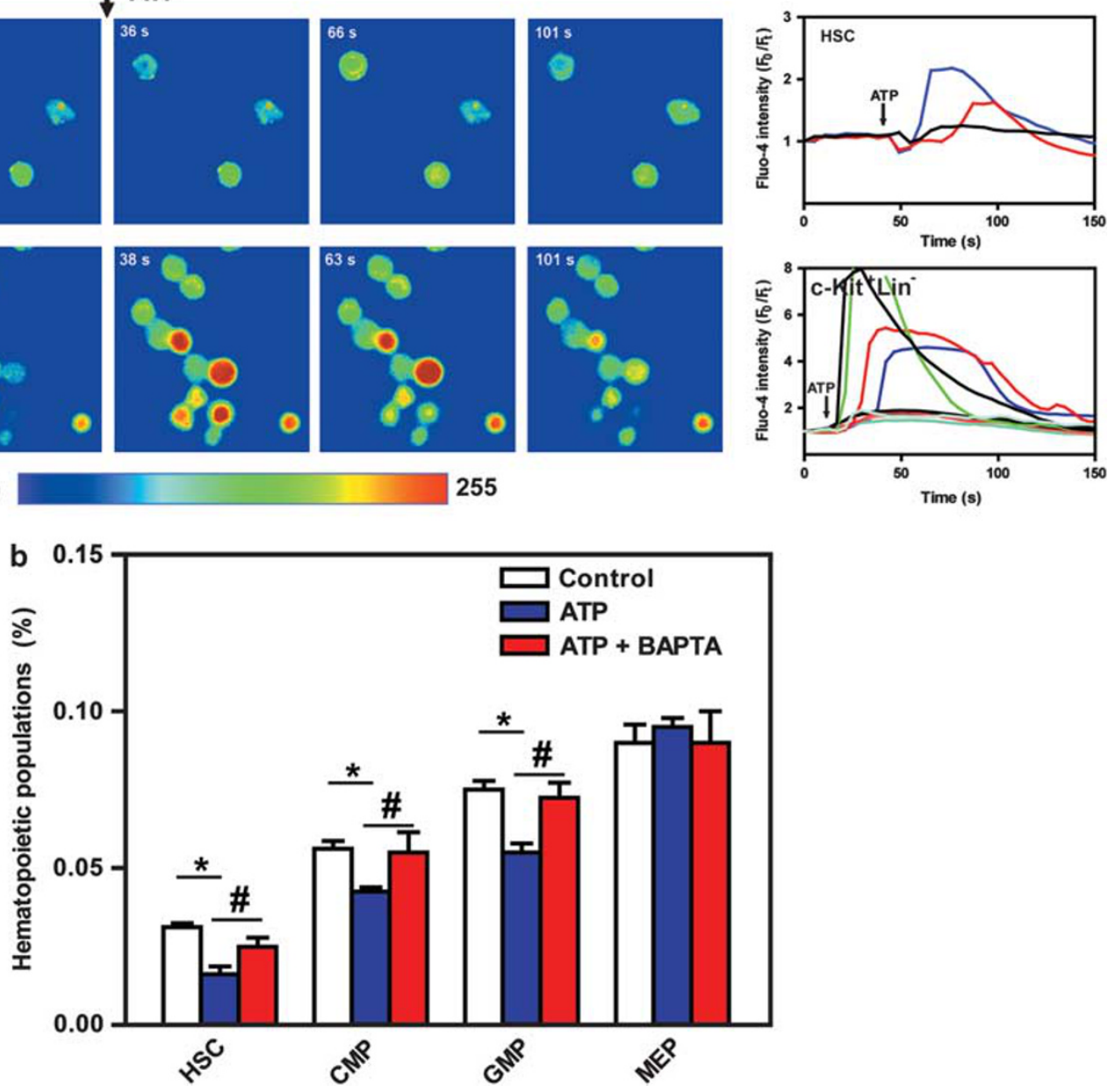

Figure 3 ATP promotes a decrease of primitive hematopoietic populations via intracellular $\mathrm{Ca}^{2+}\left(\mathrm{Ca}_{i}^{2+}\right)$. (a) Hematopoietic cells were isolated and incubated with the $\mathrm{Ca}^{2+}$ fluorophore Fluo-4-AM $(10 \mu \mathrm{M})$, and images were captured using confocal microscopy. Confocal images are shown with pseudocolor according to a fluorescence intensity scale $(0=$ blue; $255=$ red). The records of fluorescence intensity as a function of time correspond to the images shown on the right. Each line represent the $\mathrm{Ca}_{i}^{2+}$ concentration of an individual cell. ATP increased $\mathrm{Ca}_{i}^{2+}$ in hematopoietic stem cells (HSCs) and Lin-c ${ }^{-} \mathrm{Kit}^{+}$cells in a transient manner. Data are representative of at least three experiments. (b) Bone marrow suspensions were stimulated with $1 \mathrm{mM}$ ATP for $4 \mathrm{~h}$, and the hematopoietic populations present were quantified. BAPTA (1,2-bis (oaminophenoxy)ethane- $N, N, N^{\prime}, N^{\prime}$-tetraacetic acid)-AM $(10 \mu \mathrm{M})$ was incorporated into the cells for $1 \mathrm{~h}$. The reduction in the number of HSCs, common myeloid progenitor (CMPs) and granulocyte-macrophage progenitors (GMPs) by ATP was abolished in the presence of the $\mathrm{Ca}_{\mathrm{i}}^{2+}$ chelator BAPTA. ${ }^{*} \#<<0.05$. ${ }^{*}$ Statistical analysis was performed against a control. "Statistical analysis was performed against samples stimulated with ATP. ANOVA test. $n=4$

results. The counts of different cell types in the LTBMCs indicated a reduction in the number of the immature and blast forms induced by ATP in LTBMCs, and this effect was inhibited in the presence of cytokines (Table 1).

Finally, we determined whether previous stimulation with cytokines would prevent the ATP-dependent decrease in the HSC reconstitution capacity. Thus, bone marrow cells from $\mathrm{GFP}^{+}$animals were incubated for 5 min with GM-CSF $(10 \mathrm{ng} / \mathrm{ml})$ and IL-3 $(10 \mathrm{ng} / \mathrm{ml})$ before stimulation with ATP for $4 \mathrm{~h}$. These cells were then injected into sublethally irradiated animals. After 8 weeks, the bone marrow cells were extracted, and the percentages of $\mathrm{GFP}^{+}$cells within different hematopoietic populations were calculated. As shown in Figure 6, pretreatment with cytokines followed by $4 \mathrm{~h}$ of stimulation with ATP led to a recovery in the reconstitution ability of HSCs. A significant increase in $\mathrm{GFP}^{+}$cells was observed within the immature population (HSC, HP and MP) and the mature myeloid population $\left(\mathrm{Gr}-1^{+} \mathrm{Mac}-1^{+}\right)$compared with the group treated with ATP alone.

\section{Discussion}

Under physiological conditions, HSCs exhibit a quiescent state and asymmetric proliferation following an interaction with particular osteoblasts in the trabecula bone area. In contrast, myeloid differentiation occurs adjacent to blood vessels. ${ }^{3,4}$ In addition, some types of unidentified osteoblast and endothelial cells can release ATP in response to certain stimuli or physiological conditions. ${ }^{8-10}$

ATP released by the endothelium or by osteoblasts could participate in myeloid differentiation. In a previous report, we showed that ATP and its analogs could induce the transient proliferation and myeloid differentiation of primitive HPs present in LTBMCs through the activation of P2 receptors. ${ }^{6}$ 
a
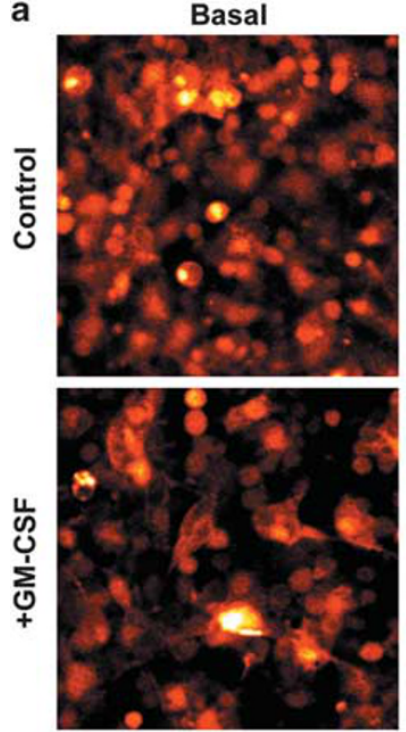

ATP
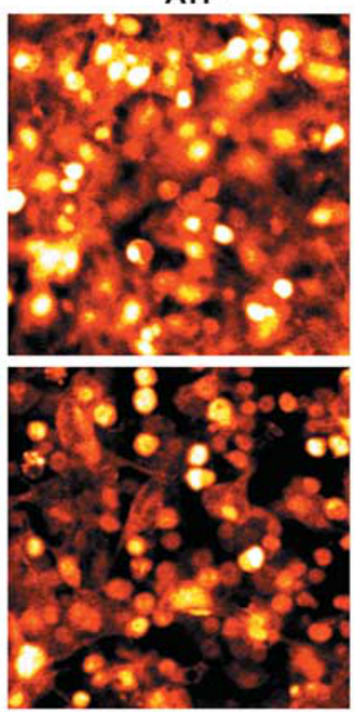

0

0

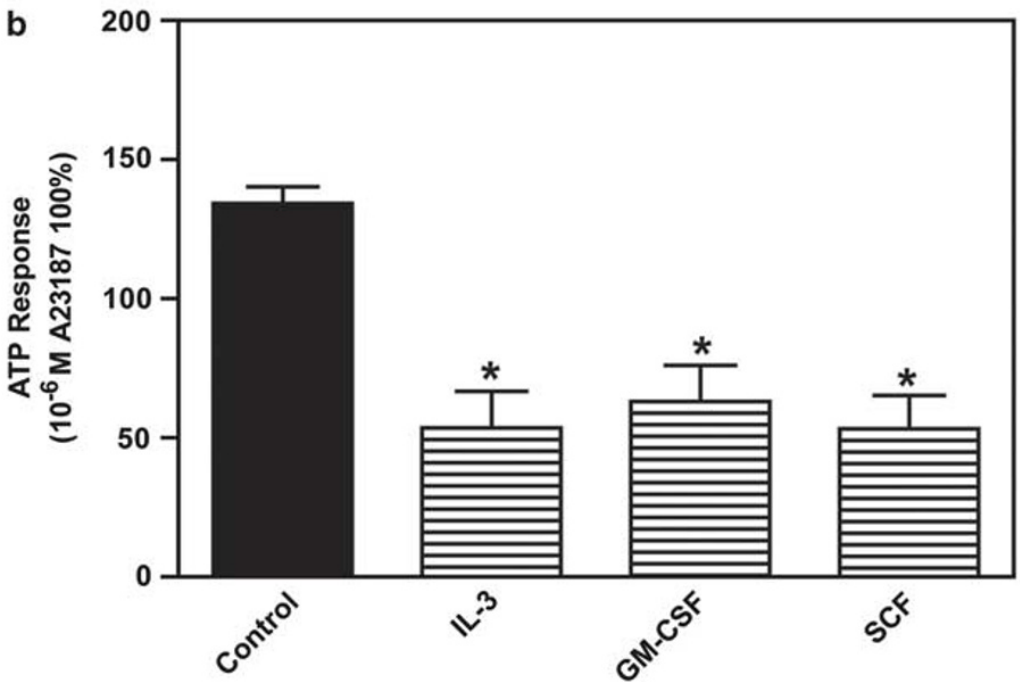

Figure 4 Cytokines partially inhibit the ATP-induced intracellular $\mathrm{Ca}^{2+}$ concentration $\left(\left[\mathrm{Ca}^{2+}\right]_{\mathrm{i}}\right)$ increase in long-term bone marrow cultures (LTBMCs). LTBMCs were incubated with the $\mathrm{Ca}^{2+}$ fluorophore Fluo-4-AM $(10 \mu \mathrm{M})$, and images were captured using confocal microscopy. LTBMCs were stimulated with $1 \mathrm{mM}$ ATP in the presence or absence of cytokines (granulocyte-monocyte colony stimulator factor (GM-CSF), stem cell factor (SCF) and interleukin-3 (IL-3): $10 \mathrm{ng} / \mathrm{ml}$ ). (a) Confocal images are shown with pseudocolor according to a fluorescence intensity scale $\left(0=\right.$ black; $255=$ white). Representative images of basal $\left[\mathrm{Ca}^{2+}\right]_{\mathrm{i}}$ intensity and the intensity following ATP stimulation and administration of the $\mathrm{Ca}^{2+}$ ionophore A23187 are shown. Control corresponds to the response without previous stimulation with cytokines. The records of fluorescence intensity as a function of time correspond to the images shown on the right. The trace is a mean of 10-20 cells. (b) The average increase in the $\mathrm{Ca}_{i}^{2+}$ concentration elicited by ATP. The increase in $\left[\mathrm{Ca}^{2+}\right]_{\mathrm{i}}$ was normalized using the $\mathrm{Ca}^{2+}$ ionophore $10^{-6} \mathrm{M}$ A23187 (Response $100 \%$ ). Data are expressed as the mean \pm S.E.M. ${ }^{*} P<0.05$. ANOVA test. $n=4-5$

In light of these findings, this study was undertaken to investigate the ability of extracellular ATP to induce direct differentiation of HSC and MPs in vivo and in vitro assays.

Initially, we determined the percentage of HSCs and myeloid precursor cells (CMP, GMP and MEP) after stimulation with ATP in freshly isolated bone marrow cells. The percentages of the HSC, CMP and GMP populations present in the bone marrow were reduced by stimulation with ATP, whereas the MEP population remained unchanged (Figure 1a). Subsequently, in vivo experiments showed that treatment with ATP for 4 days led to a reduction in the number of MPs (Figure 1b) and a corresponding increase in the mature myeloid population (Figure 1c). To determine whether the observed changes in blood cell populations were associated with differentiation, we evaluated different HSC characteristics. The presence of a quiescent state, which is a characteristic of HSCs, ${ }^{2}$ was evaluated. ATP was able to reduce the number of HSCs in quiescent state (Figure 2a). In addition, we investigated whether ATP could alter the expression the receptors Notch, CxCR4 and CaSR. Notch receptors have been associated with the self-renewal, quiescence, maintenance and differentiation of HSCs, and 


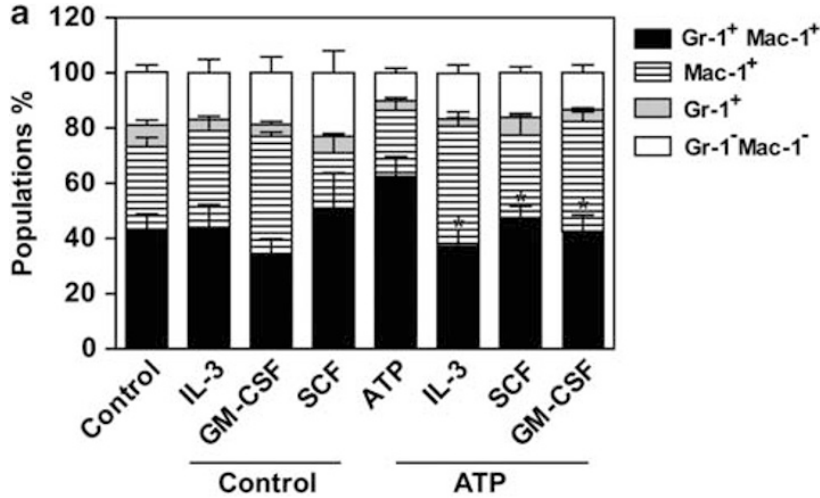

b

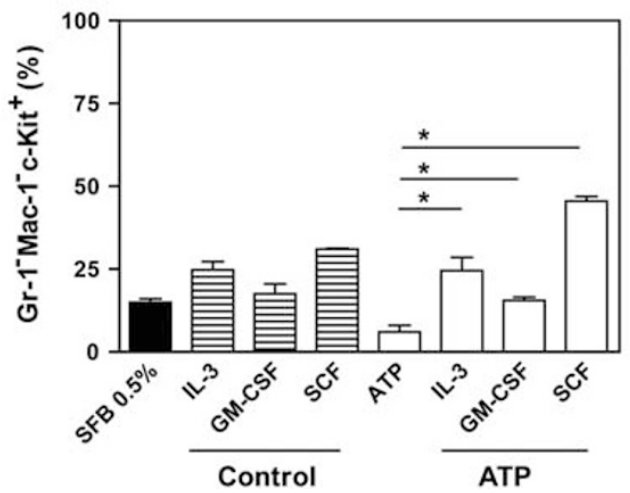

Figure 5 Cytokines inhibit ATP-induced differentiation in long-term bone marrow cultures (LTBMCs). LTBMCs were incubated for $24 \mathrm{~h}$ in Iscove's modified Dulbecco's medium (IMDM) medium supplemented with $0.5 \%$ fetal bovine serum (FBS) before stimulation with ATP in the presence or absence of cytokines (granulocyte-monocyte colony stimulator factor (GM-CSF), stem cell factor (SCF) and interleukin-3 (IL-3): $10 \mathrm{ng} / \mathrm{ml})$. The percentages represented in each histogram were obtained 3 days after stimulation with or without cytokines. Cytokines were added $5 \mathrm{~min}$ before stimulation with ATP. (a) Analysis of LTBMC populations showed that cytokines inhibit the increase of the mature Gr- ${ }^{+} \mathrm{Mac}-1^{+}$population. (b) The ATP-induced decrease in primitive hematopoietic populations (Gr-1- Mac$1^{-} \mathrm{C}^{-K i t}{ }^{+}$) was abolished in the presence of cytokines in LTBMCs. Data are expressed as the mean \pm S.E.M. ${ }^{*} P<0.05$. ANOVA test. $n=6-8$

Table 1 Statistical analysis of populations present in LTBMCs was performed following stimulation with ATP in the presence or absence of cytokines (IL-3, GM-CSF and SCF at $10 \mathrm{ng} / \mathrm{ml}$ ) after 3 days

\begin{tabular}{lccccc}
\hline & $\begin{array}{c}\text { Macro- } \\
\text { phages }\end{array}$ & $\begin{array}{c}\text { Mono- } \\
\text { cytoids }\end{array}$ & $\begin{array}{c}\text { Neu- } \\
\text { trophils }\end{array}$ & $\begin{array}{c}\text { Immature } \\
\text { forms }\end{array}$ & Blasts \\
\hline Control & $28 \pm 3^{*}$ & $29 \pm 4$ & $22 \pm 2$ & $18 \pm 1$ & $3 \pm 1$ \\
IL-3 & $38 \pm 2$ & $24 \pm 2$ & $16 \pm 3$ & $18 \pm 3$ & $4 \pm 2$ \\
GM-CSF & $40 \pm 4$ & $26 \pm 3$ & $20 \pm 4$ & $12 \pm 3$ & $2 \pm 1$ \\
SCF & $38 \pm 2$ & $21 \pm 1$ & $11 \pm 2$ & $18 \pm 1$ & $12 \pm 4$ \\
ATP & $80 \pm 4^{*}$ & $12 \pm 3^{\star}$ & $4 \pm 1^{\star}$ & $3 \pm 1^{*}$ & $1 \pm 0.5^{*}$ \\
IL-3+ATP & $52 \pm 2^{\#}$ & $10 \pm 2$ & $18 \pm 2^{\#}$ & $15 \pm 4^{\#}$ & $5 \pm 2^{\#}$ \\
GM+ATP & $54 \pm 2^{\#}$ & $8 \pm 1$ & $23 \pm 3^{\#}$ & $12 \pm 1^{\#}$ & $3 \pm 1$ \\
SCF+ATP & $48 \pm 1^{\#}$ & $9 \pm 2$ & $11 \pm 2^{\#}$ & $24 \pm 2^{\#}$ & $8 \pm 3^{\#}$ \\
\hline
\end{tabular}

The cells were stained with May-Grünwald and Giemsa solutions. Data are expressed as means \pm S.E.M. ${ }^{*}{ }^{*} P<0.05$. ${ }^{*}$ Statistical analysis was performed against a control. "Statistical analysis was performed against samples stimulated with ATP. ANOVA test. $n=6-8$

their expression is used as an indicator of the undifferentiated state of HSCs, ${ }^{27-29}$ whereas CxCR4 and CaSR are homing receptors required for the colonization of bone marrow by
HSCs during the development of hematopoiesis. ${ }^{30,31}$ ATP reduced the expression of Notch receptors (Figure $2 b$ ). However, there was no observed alteration in the expression of CxCR4 or CaSR (Supplementary Figures 7A and B). Moreover, ATP reduced the ability of HSCs to reconstitute important characteristics of HSC potency in bone marrow (Figure 2c). Therefore, we have showed that ATP reduces the HSC and primitive macrophage/granulocytic progenitor populations, leading to an increase of the mature myeloid population.

Our results showed that the observed ATP-induced differentiation occurred by $\mathrm{P} 2$ receptor activation. Participation of the P2 receptor was shown using suramin, a wellknown P2 antagonist, in vitro and in vivo experiments (Figure 1). On the other hand, the participation of $\mathrm{P} 1$ receptors, activated by adenosine, was excluded by the use of adenosine and xanthine, a P1 receptor inhibitor (Supplementary Figure 5). However, the identification of the P2 receptor subtypes deserves further investigation.

In addition, the maintenance of HSCs in a quiescent state in the osteoblast niche can also be related to a high level of ectonucleotidase expression, including that of CD39 and CD73 (Supplementary Figures 7C-F). Interestingly, primitive hematopoietic cells, characterized as $\mathrm{c}-\mathrm{Kit}^{+}$cells, showed higher ectonucleotidase activity than stromal cells and mature hematopoietic cells (whole bone marrow) (Supplementary Figure 8). These results could explain the lower differentiation effect caused by ATP in vivo assay (Figure 1b). It is possible that the high expression and activity of HSC and stromal cells reduced the differentiation induced by ATP in the hematopoietic niche. Hence, the expression and activity of ectonucleotidases arises like a new important feature to undifferentiated state. However, further investigation on the role of ectonucleotidases in hematopoietic differentiation is needed.

On the other hand, the signaling pathways involved in the differentiation by the activation of $\mathrm{P} 2$ receptors have not been completely elucidated. In fact, $\mathrm{Ca}_{\mathrm{i}}^{2+}$ signaling is the main intracellular pathway triggered by $\mathrm{P} 2$ receptors and we have shown its participation in the differentiation induced by ATP. $\mathrm{Ca}^{2+}$ is a ubiquitous messenger that controls many physiological cellular processes in different tissues, including the cells of the bone marrow microenvironment. ${ }^{6,32}$ Our results show that ATP induces an increase in $\mathrm{Ca}_{\mathrm{i}}^{2+}$ in $\mathrm{HSC}$ and $\mathrm{C}-\mathrm{Kit}^{+} \mathrm{Lin}^{-}$populations (Figure $3 \mathrm{a}$ ) and that this differentiation is $\mathrm{Ca}_{\mathrm{i}}^{2+}$ dependent (Figure $3 \mathrm{~b}$ ). The involvement of $\mathrm{Ca}^{2+}$ in cytokine-mediated signaling was recently reported by our group. ${ }^{33}$ However, the molecular mechanisms stimulated by $\mathrm{Ca}_{\mathrm{i}}^{2+}$ to carry out the response to ATP and cytokines remain unknown. The $\mathrm{Ca}_{i}^{2+}$ increase elicited by ATP is large and transiently induced in the cells studied here (Figure $3 \mathrm{a}$ ). In contrast, the change in $\mathrm{Ca}_{\mathrm{i}}^{2+}$ elicited by cytokines exhibits a short and oscillatory signal. ${ }^{6,33} \mathrm{Ca}^{2+}$ signaling stimulated by signaling molecules can influence proliferation, differentiation and cell death, and the response to $\mathrm{Ca}^{2+}$ signaling is determined by proteins that are sensitive to the intensity and duration of the $\mathrm{Ca}^{2+}$ signal. $^{32}$ It is known that activation of PLC $\gamma$, an enzyme that hydrolyzes phosphatidylinositol 4,5bisphosphate to generate the two second messengers, InsP and DAG, and cytosolic $\mathrm{Ca}^{2+}$ modulate several important 

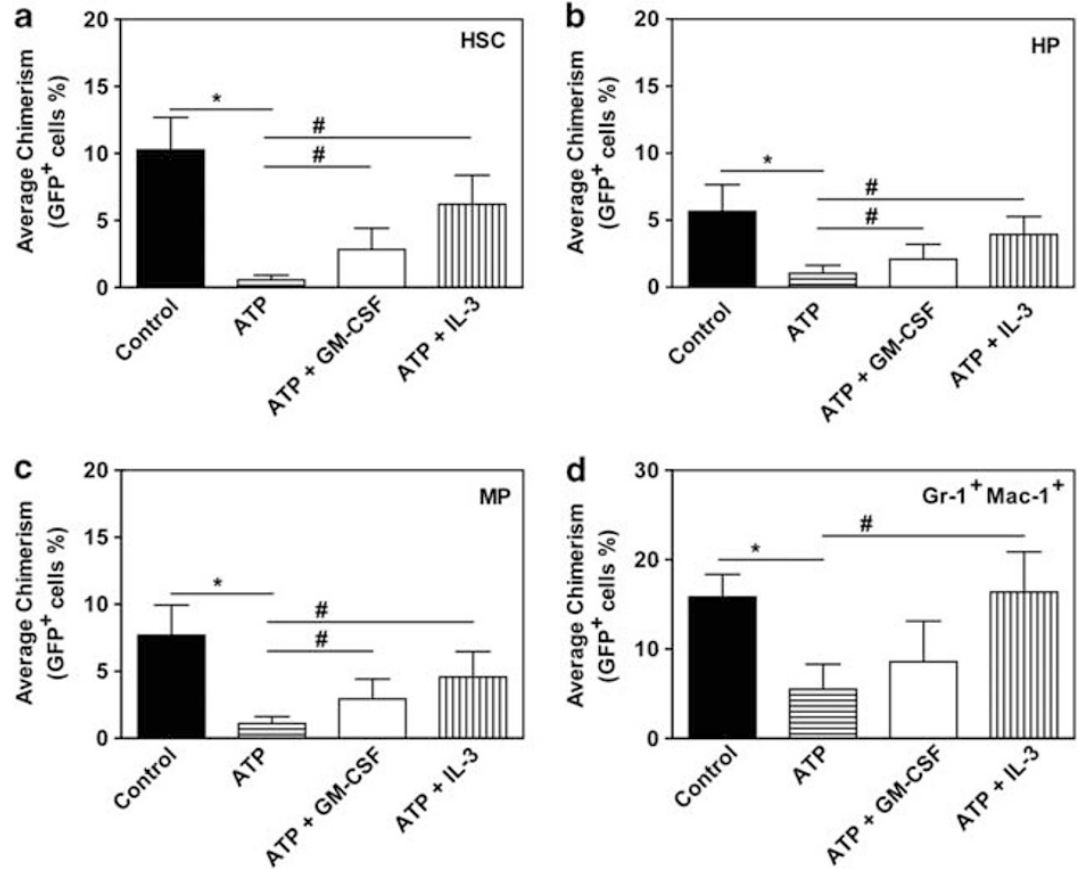

Figure 6 Cytokines recover the reconstitution capacity of hematopoietic stem cells (HSCs). Bone marrow cells extracted from green fluorescent protein (GFP) mice were stimulated with $1 \mathrm{mM} \mathrm{ATP}$ for $4 \mathrm{~h}$ and transferred to non-lethally irradiated mice. After 8 weeks, the animals were killed, and the percentage of GFP ${ }^{+}$cells were quantified in each hematopoietic population: (a) HSCs, (b) hematopoietic progenitors (HPs), (c) myeloid progenitors (MPs) and (d) the mature myeloid population (Gr-1 ${ }^{+}$ Mac- $1^{+}$). Pre-incubation with cytokines restores HSC potency after ATP stimulation. Data are expressed as the mean \pm S.E.M. ${ }^{*}{ }^{*} P<0.05$. ${ }^{*}$ Statistical analysis was performed against a control. "Statistical analysis was performed against samples stimulated with ATP. ANOVA test. $n=5-7$

transcription factor pathways required for the development or differentiation of $\mathrm{B}$ cells. ${ }^{34}$ In myeloid differentiation, the participation of PLC $\gamma 2$ by the activation of cytokines receptors was described recently. ${ }^{33}$ Moreover, an unidentified $\operatorname{PLC} \beta$ is activated by ATP in HSC, which produces $\operatorname{InsP}_{3}$ and DAG similarly to PLC $\gamma$. These two PLC isoforms can modulate hematopoiesis depending on the amount of $\mathrm{Ca}_{\mathrm{i}}^{2+}$ released. Therefore, the increase in $\mathrm{Ca}_{\mathrm{i}}^{2+}$ levels elicited by ATP or cytokines leads to different cellular effects because distinct $\mathrm{Ca}^{2+}$-sensitive proteins could be activated.

The presence of ATP in hematopoietic niches can be an important factor in regulating HSC activity together with other signaling molecules that regulate hematopoiesis, such as cytokines. Here, we show that the presence of cytokines can modulate ATP-induced differentiation. Previous stimulation of LTBMCs with cytokines reduced the effects of ATP-dependent $\mathrm{Ca}_{\mathrm{i}}^{2+}$ increases (Figure 4) and hematopoietic differentiation (Figure 5). Finally, previous incubation with cytokines also restored the ability of HSCs to repopulate bone marrow after non-lethal irradiation (Figure 6). Therefore, the intracellular pathways induced by ATP led to differentiation, whereas at the same time, cytokines and other signals activate specific pathways that regulate the maintenance of HPs.

Cytokines activate several intracellular mechanisms that could prevent some overload responses. GM-CSF was able to reduce cell death by activation of chimeric receptor GM-CSF-Bcl-XL protein. ${ }^{35}$ In addition, moderate elevation of $\mathrm{Ca}_{\mathrm{i}}^{2+}$ concentration also induces cytokine-independent survival and proliferation of human myelo-erythroid CD34 ${ }^{+}$ leukemia cell line. ${ }^{36}$. The low increase of $\mathrm{Ca}_{\mathrm{i}}^{2+}$ concentration by cytokines probably activates the mechanism related with survival decreasing the ATP-induced differentiation.

The results of this study show that extracellular ATP decreases HSC and MPs populations, promoting myeloid differentiation. Moreover, we showed that cytokines are able to modulate ATP-induced differentiation. These findings are important for understanding the HSC niche and point out the importance of the ATP and the P2 receptors in the hematopoiesis.

\section{Materials and Methods}

Animals. The wild-type mice (C57BL/6, 8-12 weeks old) used in this study were supplied by the INFAR/UNIFESP Animal Facility (São Paulo, Brazil), and the GFP mice (C57BL/6-Tg(act-EGFP)C14-Y01-FM1310sb) were maintained at CEDEME/ UNIFESP. All experiments were approved by the Animal Care and Ethics Committee of the Federal University of São Paulo (0254/08).

In vivo assays. Solutions of nucleotides in saline were prepared as described by Rapaport. ${ }^{26}$ Briefly, $0.47 \mathrm{~g} / \mathrm{kg}$ of ATP was diluted in saline (sterile saline, $\mathrm{pH} 6.2$ ) and intraperitoneally injected daily for 4 days. A control group received an equivalent volume of the vehicle daily (sterile saline) by intraperitoneally injection. ${ }^{25,26}$ In some experiments, $10 \mathrm{mg} / \mathrm{kg}$ suramin ${ }^{37}$ and $3 \mu \mathrm{g} / \mathrm{kg}$ xanthine ${ }^{38}$ were applied $1 \mathrm{~h}$ before to ATP injection.

Quantification of hematopoietic populations. Bone marrow cells were extracted from femurs and stimulated with ATP at $37^{\circ} \mathrm{C}$ for $4 \mathrm{~h}$. All experiments up to $4 \mathrm{~h}$ were performed in a physiological solution $(137 \mathrm{mM} \mathrm{NaCl}, 2.68 \mathrm{mM} \mathrm{KCl}$, $1.36 \mathrm{mM} \mathrm{CaCl}_{2}, 0.49 \mathrm{mM} \mathrm{MgCl}_{2}, 12 \mathrm{mM} \mathrm{NaHCO}_{3}, 0.36 \mathrm{mM} \mathrm{NaH}_{2} \mathrm{PO}_{4}$, and $5.5 \mathrm{mM}$ $\mathrm{D}$-glucose). For experiments more than $12 \mathrm{~h}$ long, Iscove's modified Dulbecco's medium (IMDM) supplemented with $2 \%$ fetal bovine serum (FBS) was used. Cells were stimulated, and the percentages of each hematopoietic population were 
determined by flow cytometry and compared with the initial percentage. HP cells were identified as described previously. ${ }^{2,23}$ Mature cells were excluded using a lineage marker cocktail (Lin: PE-conjugated B220, CD3, Ter-119, CD11b and Gr-1). In addition, several antibodies (FLK-2-PE, IL-7R-PE, CD90-FITC, Sca-1-Cy7/PE and c-Kit-APC) were used to recognize a subset rich in HSCs (Lin ${ }^{-}$FLK-2 ${ }^{-}$Sca$1^{+} \mathrm{c}-\mathrm{Kit}^{+}$Thy $1.1^{+}$or $\left.\mathrm{Lin}^{-} \mathrm{FLK}-2^{-} \mathrm{Sca}-1^{+} \mathrm{c}^{+} \mathrm{Kit}^{+}\right)$; HP $\left(\mathrm{Lin}^{-} \mathrm{Sca}-1^{-} \mathrm{C}-\mathrm{Kit}^{+}\right)$, a population that contained myeloid and lymphoid progenitors; and MP ( $\mathrm{Lin}^{-} \mathrm{Sca}-$ $\left.1^{-} \mathrm{IL}-7 \mathrm{C}-\mathrm{Kit}^{+}\right)$. Moreover, CMP $\left(\mathrm{Lin}^{-} \mathrm{IL}-7 \mathrm{R}^{-} \mathrm{C}-\mathrm{Kit}^{+} \mathrm{Sca}-1^{-} \mathrm{CD} 34^{+} \mathrm{Fc} \gamma \mathrm{R}^{\mathrm{low}}\right)$, GMP

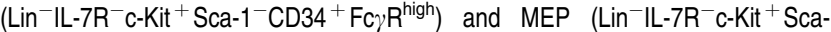
$1^{-} \mathrm{CD} 34^{-} \mathrm{Fc} \gamma \mathrm{R}^{\text {low }}$ ) populations were identified using IL-7R-PE, Sca-1-PE, c-KitCy7/PE, CD34-FITC and FC $\gamma$ R-APC antibodies. To quantify the percentage of hematopoietic populations, $3-5 \times 10^{6}$ events were acquired. All antibodies were purchased from Becton Dickinson (Franklin Lakes, NJ, USA) or eBioscience (San Diego, CA, USA). The mature bone marrow-resident myeloid populations were evaluated with antibodies that recognize granulocytic and monocytic populations (Gr-1-PE and CD11b-Cy7/PE, respectively). We captured 3000000 events to evaluate this mature population. Data analyses were performed on a FACSCalibur (Becton Dickinson) flow cytometer using the CellQuest software. The gating strategy for murine hematopoietic populations is shown in Supplementary Figure 1.

Murine $\mathrm{Lin}^{-} \mathrm{C}_{-} \mathrm{Kit}^{+}$and CFU-GM assay. Separation of the murine $\mathrm{Lin}^{-} \mathrm{C}-$ $\mathrm{Kit}^{+}$population was performed by gradient centrifugation methods using Ficoll Histopaque $\left(1.077 \mathrm{~g} / \mathrm{cm}^{3}\right)$. After mononuclear isolation, the cells were labeled with specific antibodies. For cell isolation, a biotin-conjugated Lin antibody cocktail was used, followed by incubation with anti-biotin-conjugated microbeads (Miltenyi Biotec, Columbus, $\mathrm{OH}, \mathrm{USA}$ ). After labeling, the cells were placed in a magnetic column, and the negative population was extracted. The $\mathrm{Lin}^{-}$cells were labeled with anti-c-Kit-conjugated microbeads (Miltenyi Biotec), and the $\mathrm{Lin}^{-} \mathrm{c}-\mathrm{Kit}^{+}$ population was isolated in a magnetic column.

CFU assays were performed by plating $5 \times 10^{3}$ murine $\left(\mathrm{Lin}^{-} \mathrm{C}-\mathrm{Kit}{ }^{+}\right)$bone marrow cells in methylcellulose-based medium with recombinant cytokines and EPO (Methocult M3434; Stem Cell Technologies, Vancouver, Canada) in 35-mm diameter dishes. The cells were cultured in a fully humidified air incubator under $5 \%$ $\mathrm{CO}_{2}$ at $37^{\circ} \mathrm{C}$ for 7 or 14 days for murine and human cells, respectively. At the end of the incubation period, colonies of more than 50 cells were counted using a dark-field microscope.

Notch and Ki-67 expression. Bone marrow cells were stimulated with ATP at $37^{\circ} \mathrm{C}$ for 2 or $4 \mathrm{~h}$ in a physiological solution. Subsequently, cells were fixed with $2 \%$ paraformaldehyde for $30 \mathrm{~min}$, washed with $0.1 \mathrm{M}$ glycine and permeabilized with $0.01 \%$ saponin for $15 \mathrm{~min}$. The cells were incubated for $2 \mathrm{~h}$ with rabbit purified antiNotch-1 or anti-Ki-67-Alexa Fluor-488 conjugated (Becton Dickinson). Anti-rabbit IgG-Alexa Fluor 488 conjugates (Molecular Probes/Invitrogen, Eugene, OR, USA) was used as secondary antibody against anti-Notch-1 and incubated for $40 \mathrm{~min}$. Notch and Ki-67 expression were evaluated in hematopoietic populations using the antibodies described above. Data analyses were performed on a FACSCalibur flow cytometer using the CellQuest software.

Competitive repopulation assay. Whole bone marrow cells of GFP transgenic mice were stimulated with $1 \mathrm{mM}$ ATP in the presence or absence of GM$\operatorname{CSF}(10 \mathrm{ng} / \mathrm{ml})$ and IL-3 $(10 \mathrm{ng} / \mathrm{ml})$ in physiological solution at $37^{\circ} \mathrm{C}$ for $4 \mathrm{~h}$ and then injected ( $10^{6}$ cells per animal) into wild-type sublethally irradiated mice (700 Gy). The frequency of GFP ${ }^{+}$bone marrow cells in each hematopoietic population (HSC, $\mathrm{HP}, \mathrm{MP}$ and $\mathrm{Gr}-1^{+} \mathrm{Mac}-1^{+}$) was quantified at 8 weeks post-transfer using a FACSCalibur flow cytometer.

Dexter-type cultures. Dexter-type cultures or LTBMCs were prepared following the method of Dexter et al. ${ }^{39}$ with some modifications. Briefly, total bone marrow cells were plated onto 12-well plates and fed weekly with IMDM supplemented with 5\% FBS (Cultilab, Rio Grande do Sul, Brazil), 20\% horse serum (Stemcell Technologies) and $10^{-6} \mathrm{M}$ hydrocortisone (Sigma-Aldrich, St Louis, MO, USA). Cultures were maintained at $37^{\circ} \mathrm{C}$ in a humid chamber with $5 \% \mathrm{CO}_{2}$. After the establishment of a confluent stroma layer, the remaining non-adherent cells were removed, and $10^{6}$ cells per well was added to precultured stroma cultures, along with fresh media. After 1 week of co-culture, the cells were further cultured in IMDM with $0.5 \%$ FBS for $24 \mathrm{~h}$. Subsequently, LTMBCs were stimulated with ATP in the presence or absence of IL-3, GM-CSF and SCF. After 3 days, the cells were collected for immunophenotyping using the antibodies Gr-1-FITC, Mac-1-PE and c-Kit-APC. Data analyses were performed on a FACSCalibur flow cytometer
(Becton Dickinson). In addition, co-cultured cells were stained with May-Grünwald and Giemsa solution (Sigma) and identified by morphological characteristics.

Calcium measurements by confocal microscopy. $\mathrm{Lin}^{-} \mathrm{c}-\mathrm{Kit}^{+}$and HSC populations were previously isolated to measure $\mathrm{Ca}_{i}^{2+}$. The Lin ${ }^{-}$cells were isolated as described above. HSC isolation was performed by cell sorting in a FACSCalibur flow cytometer.

After the separation of populations, the cells were cytocentrifuged onto glass coverslips $(25 \mathrm{~mm})$. For intracellular $\mathrm{Ca}^{2+}$ concentration $\left(\left[\mathrm{Ca}^{2+}\right]_{\mathrm{i}}\right)$ measurements, the isolated cells or LTBMCs were incubated for $40 \mathrm{~min}$ at room temperature with $10 \mu \mathrm{M}$ Fluo-4/AM (Molecular Probes/Invitrogen) and $0.01 \%$ pluronic acid (Molecular Probes/Invitrogen) and washed with physiological solution. Images were captured with a microscope (Zeiss, Axiovert 100M, Oberkochen, Germany) equipped with a laser scanner (Zeiss, LSM 510 META) and a $63 \times$ objective (Plan-Neofluor, 1.4 numerical aperture) under oil immersion. The Fluo-4 probe was excited with an argon laser $\left(\lambda_{\mathrm{Ex}}=488 \mathrm{~nm}\right)$, and light emission was detected using a Zeiss META detector $\left(\lambda_{\mathrm{Em}}=500-550 \mathrm{~nm}\right)$. The pinhole device was not used for $\mathrm{Ca}_{i}^{2+}$ measurements. Images were collected at approximately 4- to 6-s intervals. Fluorescence intensity was normalized with reference to basal fluorescence using the Examiner 3.2 (Zeiss) and Spectralyzer (NJ, USA) software. Representative pseudocolored images are shown with reference to the basal intensity on a fluorescence intensity scale ranging from 0 (black or blue) to 255 (white or red).

Statistical analysis. $\mathrm{Ca}^{2+}$ mobilization in response to ATP was normalized with reference to the response to $10^{-6} \mathrm{M} A 23187(100 \%)$, and results were presented as representative pseudocolored images according to a fluorescence intensity scale. Data were expressed as means \pm S.E.M. Statistical analyses were performed using Student's $t$-test for comparisons between two groups, and analysis of variance and Dunnett's post hoc test were used for multiple comparisons among groups. Values of $P<0.05$ were considered statistically significant.

\section{Conflict of Interest}

The authors declare no conflict of interest.

Acknowledgements. This work was supported by grants from the 'Fundação de Amparo à Pesquisa do Estado de São Paulo' (FAPESP). CMVB was supported by a doctoral fellowship from FAPESP (2007/58589-9).

1. Nilsson SK, Johnston HM, Coverdale JA. Spatial localization of transplanted hemopoietic stem cells: inferences for the localization of stem cell niches. Blood 2001; 97: 2293-2299.

2. Passegue E, Wagers AJ, Giuriato S, Anderson WC, Weissman IL. Global analysis of proliferation and cell cycle gene expression in the regulation of hematopoietic stem and progenitor cell fates. J Exp Med 2005; 202: 1599-1611.

3. Zhang J, Niu C, Ye L, Huang H, He X, Tong WG et al. Identification of the haematopoietic stem cell niche and control of the niche size. Nature 2003; 425: 836-841.

4. Yin T, Li L. The stem cell niches in bone. J Clin Invest 2006; 116: 1195-1201.

5. North TE, Goessling W, Walkley CR, Lengerke C, Kopani KR, Lord AM et al. Prostaglandin E2 regulates vertebrate haematopoietic stem cell homeostasis. Nature 2007; 447: 1007-1011.

6. Paredes-Gamero EJ, Leon CM, Borojevic R, Oshiro ME, Ferreira AT. Changes in intracellular $\mathrm{Ca}^{2+}$ levels induced by cytokines and $\mathrm{p} 2$ agonists differentially modulate proliferation or commitment with macrophage differentiation in murine hematopoietic cells. J Biol Chem 2008; 283: 31909-31919.

7. Lemoli RM, Ferrari D, Fogli M, Rossi L, Pizzirani C, Forchap S et al. Extracellular nucleotides are potent stimulators of human hematopoietic stem cells in vitro and in vivo. Blood 2004; 104: 1662-1670.

8. Kawai Y, Yokoyama Y, Kaidoh M, Ohhashi T. Shear stress-induced ATP-mediated endothelial constitutive nitric oxide synthase expression in human lymphatic endothelial cells. Am J Physiol Cell Physiol 2010; 298: C647-C655.

9. Alvarenga EC, Rodrigues R, Caricati-Neto A, Silva FC, Paredes-Gamero EJ, Ferreira AT. Low-intensity pulsed ultrasound-dependent osteoblast proliferation occurs by via activation of the P2Y receptor: role of the P2Y(1) receptor. Bone 2010; 46: 355-362.

10. Hayton MJ, Dillon JP, Glynn D, Curran JM, Gallagher JA, Buckley KA. Involvement of adenosine $5^{\prime}$-triphosphate in ultrasound-induced fracture repair. Ultrasound Med Biol 2005; 31: 1131-1138.

11. Abbracchio MP, Burnstock G. Purinoceptors: are there families of P2X and P2Y purinoceptors? Pharmacol Ther 1994; 64: 445-475. 
12. Nicholas RA, Lazarowski ER, Watt WC, Li Q, Boyer J, Harden TK. Pharmacological and second messenger signalling selectivities of cloned P2Y receptors. J Auton Pharmacol 1996; 16: 319-323

13. Suh BC, Kim TD, Lee IS, Kim KT. Differential regulation of $P 2 Y(11)$ receptor-mediated signalling to phospholipase $C$ and adenylyl cyclase by protein kinase $C$ in $\mathrm{HL}-60$ promyelocytes. Br J Pharmacol 2000; 131: 489-497.

14. Takasaki J, Kamohara M, Saito T, Matsumoto M, Matsumoto S, Ohishi T et al. Molecular cloning of the platelet P2T(AC) ADP receptor: pharmacological comparison with another ADP receptor, the P2Y(1) receptor. Mol Pharmacol 2001; 60: 432-439.

15. Giltaire $S$, Lambert $S$, Poumay Y. HB-EGF synthesis and release induced by cholestero depletion of human epidermal keratinocytes is controlled by extracellular ATP and involves both p38 and ERK1/2 signaling pathways. J Cell Physiol 2011; 226: 1651-1659.

16. Ornelas IM, Ventura AL. Involvement of the PI3K/AKT pathway in ATP-induced proliferation of developing retinal cells in culture. Int J Dev Neurosci 2010; 28: 503-511.

17. Paredes-Gamero EJ, Dreyfuss JL, Nader HB, Miyamoto Oshiro ME, Ferreira AT. P2X7-induced apoptosis decreases by aging in mice myeloblasts. Exp Gerontol 2007; 42 320-326.

18. Costa-Junior HM, Hamaty FC, da Silva Farias R, Einicker-Lamas M, da Silva MH, Persechini PM. Apoptosis-inducing factor of a cytotoxic T cell line: involvement of a secretory phospholipase A2. Cell Tissue Res 2006; 324: 255-266.

19. Communi D, Janssens R, Robaye B, Zeelis N, Boeynaems JM. Rapid up-regulation of P2Y messengers during granulocytic differentiation of HL-60 cells. FEBS Lett 2000; 475: 39-42.

20. Adrian K, Bernhard MK, Breitinger HG, Ogilvie A. Expression of purinergic receptors (ionotropic P2X1-7 and metabotropic P2Y1-11) during myeloid differentiation of $\mathrm{HL} 60$ cells. Biochim Biophys Acta 2000; 1492: 127-138.

21. Rossi L, Manfredini R, Bertolini F, Ferrari D, Fogli M, Zini R et al. The extracellular nucleotide UTP is a potent inducer of hematopoietic stem cell migration. Blood 2007; 109 533-542.

22. Casati A, Frascoli M, Traggiai E, Proietti M, Schenk U, Grassi F. Cell-autonomous regulation of hematopoietic stem cell cycling activity by ATP. Cell Death Differ 2011; 18: 396-404

23. Christensen JL, Weissman IL. Flk-2 is a marker in hematopoietic stem cell differentiation: a simple method to isolate long-term stem cells. Proc Natl Acad Sci USA 2001; 98: 14541-14546.

24. Paredes-Gamero EJ, Craveiro RB, Pesquero JB, Franca JP, Oshiro ME, Ferreira AT. Activation of $\mathrm{P} 2 \mathrm{Y} 1$ receptor triggers two calcium signaling pathways in bone marrow erythroblasts. Eur J Pharmacol 2006; 534: 30-38.

25. Shabbir M, Thompson C, Jarmulowiczc M, Mikhailidis D, Burnstock G. Effect of extracellular ATP on the growth of hormone-refractory prostate cancer in vivo. BJU Int 2008; 102: 108-112.

26. Rapaport E. Experimental cancer therapy in mice by adenine nucleotides. Eur $\mathrm{J}$ Cancer Clin Oncol 1988; 24: 1491-1497.
27. Duncan AW, Rattis FM, DiMascio LN, Congdon KL, Pazianos G, Zhao C et al. Integration of Notch and Wnt signaling in hematopoietic stem cell maintenance. Nat Immunol 2005; 6 314-322.

28. Reya T, Duncan AW, Ailles L, Domen J, Scherer DC, Willert $K$ et al. A role for Wnt signalling in self-renewal of haematopoietic stem cells. Nature 2003; 423: 409-414

29. Maillard I, He Y, Pear WS. From the yolk sac to the spleen: new roles for Notch in regulating hematopoiesis. Immunity 2003; 18: 587-589.

30. Kiel MJ, Morrison SJ. Maintaining hematopoietic stem cells in the vascular niche. Immunity 2006; 25: 862-864.

31. Adams GB, Chabner KT, Alley IR, Olson DP, Szczepiorkowski ZM, Poznansky MC et al. Stem cell engraftment at the endosteal niche is specified by the calcium-sensing receptor. Nature 2006; 439: 599-603.

32. Cook SJ, Lockyer PJ. Recent advances in $\mathrm{Ca}(2+)$-dependent Ras regulation and cell proliferation. Cell Calcium 2006; 39: 101-112.

33. Leon CM, Barbosa CM, Justo GZ, Borelli P, Resende JDJ, Oliveira JS et al. Requirement for PLCgamma2 in IL-3 and GM-CSF-stimulated MEK/ERK phosphorylation in murine and human hematopoietic stem/progenitor cells. J Cell Physiol 2011; 226: 1780-1792.

34. Scharenberg AM, Humphries LA, Rawlings DJ. Calcium signalling and cell-fate choice in $B$ cells. Nat Rev Immunol 2007; 7: 778-789.

35. Antignani A, Youle RJ. The cytokine, granulocyte-macrophage colony-stimulating facto (GM-CSF), can deliver Bcl-XL as an extracellular fusion protein to protect cells from apoptosis and retain differentiation induction. J Biol Chem 2007; 282: 11246-11254.

36. Apati A, Janossy J, Brozik A, Bauer PI, Magocsi M. Calcium induces cell survival and proliferation through the activation of the MAPK pathway in a human hormone-dependen leukemia cell line, TF-1. J Biol Chem 2003; 278: 9235-9243.

37. Yang DM, Teng HC, Chen KH, Tsai ML, Lee TK, Chou YC et al. Clodronate-induced cell apoptosis in human thyroid carcinoma is mediated via the $\mathrm{P} 2$ receptor signaling pathway. J Pharmacol Exp Ther 2009; 330: 613-623.

38. Mino RP, Spoerri PE, Caballero S, Player D, Belardinelli L, Biaggioni I et al. Adenosine receptor antagonists and retinal neovascularization in vivo. Invest Ophthalmol Vis Sci 2001; 42: 3320-3324.

39. Dexter TM, Allen TD, Lajtha LG. Conditions controlling the proliferation of haemopoietic stem cells in vitro. J Cell Physiol 1977; 91: 335-344.

Cell Death and Disease is an open-access journal published by Nature Publishing Group. This work is licensed under the Creative Commons Attribution-Noncommercial-No Derivative Works 3.0 Unported License. To view a copy of this license, visit http://creativecommons.org/licenses/by-nc-nd/3.0/

Supplementary Information accompanies the paper on Cell Death and Disease website (http://www.nature.com/cddis) 